\title{
Chemo-entrepreneurship Modelling on Chemical Bonding Materials as an Effort to Grow Entrepreneurial Spirit of Students with Hearing Impairment in (Islamic) Senior High School
}

\author{
Agus Kamaludin ${ }^{a, *}$ \\ ${ }^{a}$ Department of Chemistry Education, Faculty of Science and Technology UIN Sunan Kalijaga Yogyakarta \\ *Corresponding author: aguskamaludin@gmail.com
}

\begin{abstract}
This research aims to develop MEc Bond learning media (Magnetic Educhem Bonding) for students with hearing impairment in (Islamic) senior high school based on chemo-entrepreneurship modeling. This research uses the development model by Borg \& Gall that includes the identification of potentials and problems, product selection, literature review, planning, developing initial product draft, initial field trials and product revisions, and it ends with major field trials and product revision. The subjects of this research include material experts, media experts, disability experts, senior high school chemistry teachers and students. The data of this research are taken by using several instruments: interview guide, product quality assessment sheet, and student response sheet. The interview result is analyzed by using descriptive technique, assessment result of product quality is analyzed by using categorical descriptive quantitative technique, and student's response is analyzed by using percentage technique. The results of this research has been developed with the input from the validation specialist and chemistry teachers. Learning media which is developed has best quality, according to the assessment of chemistry teachers in (Islamic) senior high school, with the ideality percentage of $91.02 \%$. In general, students with hearing impairment might respond positively which gets the ideality percentage of $86 \%$ to the MEc Bond learning media which makes the material chemical bonds easier to be understood and fun. In addition, the media is desperately necessary for studying chemical bonding in class and it can foster entrepreneurial spirit for the students in the form of making learning media of chemical bonds.
\end{abstract}

Keywords: chemo-entrepreneurship, learning media, chemical bonds, MEc bond

\section{INTRODUCTION}

Some people think that person with disability is a problem, however for others, it is a challenge. Indonesia is still proceeding to address issues related to people with disability. People more realize that they exist among us, not to separate them from the community, but how we as their environments can adapt to accept the advantages and disadvantages of people with disabilities. As the government that has been increasingly concerned with this issue, being evidenced by the promulgation of Law no. 8 of 2016 regarding people with disabilities.

Law no. 8 of 2016 and also some regulations concerning people with disabilities mentioned that they have the same rights as others, in all areas of life, including education, employment, health, law and politics. Regarding to employment, although the percentage is small (1\% according to Law No. 4 of 1997), every business entity, whether public or private, is required to allocate jobs for people with disabilities. This quota is sometimes not even fulfilled due to lack of competence (knowledge and skills) being possessed by persons with disabilities.

This problem of competence needs to be solved since people with disabilities study formally in school. If children with disabilities get the right services, especially life skill according to their interests and potentials, then the child will be more independent. However, if it is not handled properly, the developing of children's ability will experience obstacles and become the burden of parents, family, society and state [1].

According to a study by Lembaga Penyelidikan Ekonomi dan Masyarakat (LPEM) Faculty of Economics and Business (FEB) University of Indonesia at the end of 2016, the estimated number of people with 
disabilities in Indonesia reaches $12.15 \%$ of the population or nearly 30 million people. From that number, $10.29 \%$ are people with easy disability categories, while the others $1.87 \%$ are categorized as severe. The level of education which is attained by people with disabilities is also less than other. This is one of the main factors that contribute to the low absorption of the labour of groups with disability.

Based on the results of interviews with Reswari as owner of Osiris ice cream shop whose employees are people with disabilities or from families with disabilities, the factors causing the low labour absorption of people with disabilities are: (1) employment providers have not provided opportunities for people with disabilities, (2) the abilities of people with disabilities are not in accordance with the standards which are required, (3) skills and health of people with disabilities do not meet the standards that are required by employers. Therefore, people with disabilities should be provided a skill in order to become an entrepreneur who can create their own jobs.

Entrepreneurship has emerged over the past two decades as one of the most powerful economic forces in the world. Therefore, all countries including Indonesia begin to improve their curriculum framework by incorporating this aspect into the subjects or courses. The number of colleges and universities offering programs that are related to entrepreneurship have grown from a few in 1970 to over 1,600 in 2005 [2]. It indicates that having the spirit of entrepreneurship is one of the important things today.

Several literatures mention that the spirit of entrepreneurship is important because it can improve the ability of human resources, strengthen the potency of students through education of skills and social services by applying the principles of mutual cooperation, togetherness, self-supporting, and participation. In addition, it also can give the motivation to advance from the helplessness in order to be able to live independently and able to work, especially to create jobs in the community [3].

The use of the term entrepreneurship also began to be widely adapted by various backgrounds and expertise to merge with the field of cultivation which will be developed. For example, it is now known as the term edupreneurship and chemo-entrepreneurship. Dewi, Yani, and Suhardini [4] stated that entrepreneurship education in schools can be implemented in an integrated manner in various activities. Some entrepreneurship education models in schools may take the form of: (a) entrepreneurship education which is contained in all subjects, (b) entrepreneurship education contained in extracurricular activities, (c) entrepreneurship education in self-development, (d) entrepreneurship education practicing theory, (e) entrepreneurship education in books and teaching materials, (f) entrepreneurship education through the establishment of school culture, $(\mathrm{g})$ incorporating entrepreneurship education in local school content.

One of the models of entrepreneurship education that will be conducted through this research is the entrepreneurship education which is contained in chemistry subjects. Students with disabilities will be invited to practice the concepts of entrepreneurship in the field of chemistry (Chemo-entrepreneurship) through manufacturing of a product that has economic value. One of the materials that can be developed through Chemo-entrepreneurship is the material of chemical bonds.

As revealed by Gabel and Johnston in Wu [5], chemistry is a complex field of study because in chemistry there are three levels of representation, which include microscopic, macroscopic, and symbolic levels. This complex understanding requires a high reasoning to solve the problems in the concept of chemistry, especially at the microscopic level. To solve these problems, students sometimes make their own interpretations of a concept they learn. However, the interpretive results that exist in the students' cognitive structure concerning on a concept are sometimes unsuited or even in contradiction to the concepts proposed by chemists.

Chemical Bonding Material is one of the chemical materials that requires high power of reason. This material has an abstract concept, so it requires learning media to explain in order to become more concrete and easy to be studied. Students experience difficulties, especially in determining the compound that has ionic bonds, determining the formula of the compound formed and the types of bond, determining the compound that does not meet the octet rule, determining the polar compound, determining the pair of elements that can form ionic bonds and pairs of elements that can form bonds covalent [6]. These difficulties are more experienced by students with disabilities because when studying in inclusive class (where students with disability learn with their normal friends), most teachers only use Student Worksheet (LKS) to explain the materials (interview with Karyadi as chemistry teacher at Sewon senior high school 1 Bantul). If students with disabilities still have difficulties in understanding the materials, then the Class Companion Teachers (GPK) will provide material outside the lesson.

Chemo-entrepreneurship is one of the learning media that will help to concrete the material of chemical bond, so that student's understanding about this material becomes better. Besides, it is also expected to 
be able to increase creativity (because students with disability later will be guided to make product) as well as retentive power to this material. Ultimately, it is expected that by the increasing of students' retentive power will improve learning outcomes [7]. In addition, the more major, students can learn the process of manufacturing materials into a useful and economically precious product so that it can grow the spirit of entrepreneurship.

\section{METHOD}

\section{Research Design}

This research is a type of research and development (R \& D) research that aims to develop chemoentrepreneurship-based learning media for students with disabilities in (Islamic) high school, through initial assessment (need assessment), product development, and final research (effectiveness test). The development model which is used in this study adapts the research steps of development by Borg \& Gall

[8]. The development procedure includes several stages, namely:

1. Identification of potentials and problems, i.e. conducting preliminary research on chemistry learning in (Islamic) senior high school and its influencing factors, including curriculum, teachers, teaching materials, and student characteristics. Identification of potentials and problems is also focused on the selection of materials in accordance with the concept of chemo-entrepreneurship.

2. Selection of the product, i.e. selecting the product to be made tentative outline of what will be included on the product and how the product will be used, specific statement about the purpose of the product being made. The products to be developed to improve understanding of the concept of chemical bonds and entrepreneurial spirit of the students with hearing impairment by making the learning media of chemical bond in the form of three dimensional media using magnet (Magnetic Educhem Bonding (MEc Bond)).

3. Literature review, i.e., determining and taking into account the basic knowledge in the field which becomes the focus of research, in this case study / review focuses on the literatures which are related to the problem of student competence, chemo-entrepreneurship, and research on development through journals and other supporting references.

4. Planning, i.e., determining the specific goals to be achieved by the product to be made, the purpose of using the product, who the user of the product is, the description of the components of the product and its use.

5. The development of the initial product draft, developed through cooperation with professionals or people who have the necessary skills for its development. The expert who will be involved in this research is the material experts (especially the materials of chemical bonding), the media experts (expertise who works in the field of making learning media that has the economic and sale value), and experts of inclusive education / disability.

6. Initial field trials and product revisions, in this case a preliminary test was conducted through an initial product assessment by two material experts, two media experts, two disability experts, and five teachers of (Islamic) high school chemistry.

7. The main stage of field trials (small scale) and product revision. This stage will be done by testing the final product for students with disabilities and requesting their responses about the product. After that, it will be conducted interview/ filling the questionnaire to reveal how far the product which is produced through this study is able to increase the entrepreneurial spirit of students with hearing impairment.

\section{Data Collection Technique}

Data collection technique in this study is a non-test technique by using questionnaire and observation methods. The data collection instruments used are statement sheets, and suggestions and critics for experts (materials, media, disabled), evaluation sheets o quality of learning media for teachers as reviewers, and response sheets to the learning media for students.

\section{Data Analysis Technique}

In accordance with the purpose of this development research, the data to be obtained and the instruments used in this research include:

1. Qualitative data on the process of developing steps $1-5$ are obtained through descriptive notes and statement sheets and suggestions by material experts, media experts, and disability experts. 
2. Quantitative data in the form of field trial result data of the main stage againts learning media of MEc Bond (Magnetic Educhem Bonding) which have been developed are obtained through the assessment sheet of the quality of learning media.

Qualitative data which are obtained will be analyzed descriptively, while quantitative data (product trial) will be analyzed by using quantitative descriptive method following steps:

The data of product quality are obtained from material experts, media experts, disability experts, and teachers by using a five-scale model. Data which are obtained then are analyzed further to find out the quality of learning media by the steps as follows:

1. The results of the assessment of five high school chemistry teachers as reviewers who are still in the form of letters are converted into a score with a scale of five, namely: Very less $=1$, Less $(L)=2$, Enough $(E)=3$, Good $(G)=4$, Very good $(V G)=5$.

2. Calculate the average score of each sub aspect of each aspect assessed by the formula:

$\mathrm{X}=\frac{\sum \mathrm{X}}{\mathrm{n}}$

with:

$\mathrm{X}=$ average score of each sub aspect

$\Sigma \mathrm{X}=$ total score of each sub aspect

$\mathrm{n}=$ number of appraisers

3. Change the average score of each sub aspect in the form of quantitative data into qualitative criteria in accordance with the criteria of assessment category of each aspect with the provisions as described in Table 1. below [6]:

TABLE 1. The Criteria of Ideal Assessment Categories

\begin{tabular}{ccc}
\hline No & Score Range (i) & Category \\
\hline 1. & $\overline{\mathrm{X}}>\mathrm{M}_{\mathrm{i}}+1,5 \mathrm{SB}_{\mathrm{i}}$ & Very Good \\
2. & $\mathrm{M}_{\mathrm{i}}+0,5 \mathrm{SB}_{\mathrm{i}}<\overline{\mathrm{X}} \leq \mathrm{M}_{\mathrm{i}}+1,5 \mathrm{SB}_{\mathrm{i}}$ & Good \\
3. & $\mathrm{M}_{\mathrm{i}}-0,5 \mathrm{SB}_{\mathrm{i}}<\overline{\mathrm{X}} \leq \mathrm{M}_{\mathrm{i}}+0,5 \mathrm{SB}_{\mathrm{i}}$ & Enough \\
4. & $\mathrm{M}_{\mathrm{i}}-1,5 \mathrm{SB}_{\mathrm{i}}<\overline{\mathrm{X}} \leq \mathrm{M}_{\mathrm{i}}-0,5 \mathrm{SB}_{\mathrm{i}}$ & Less \\
5. & $\overline{\mathrm{X}} \leq \mathrm{M}_{\mathrm{i}}-1,5 \mathrm{SB}_{\mathrm{i}}$ & Very Less \\
\hline
\end{tabular}

According to Arifin [9], the value of $\mathrm{M}_{\mathrm{i}}$ and $\mathrm{SB}_{\mathrm{i}}$ can be obtained by the following formula:

$\mathrm{Mi}_{\mathrm{i}}=$ Mean ideal

$\mathrm{SB}_{\mathrm{i}}=$ total score of each sub aspect

with:

$\mathrm{M}_{\mathrm{i}}=\frac{1}{2}$ (ideal highest score + ideal lowest score)

$\mathrm{SB}_{\mathrm{i}}=\left(\frac{1}{2}\right)\left(\frac{1}{3}\right)$ (ideal highest score - ideal lowest score)

4. Calculating the average score of each aspect of the assessment by using the formula:

$$
\begin{aligned}
& \bar{Y}=\frac{\sum Y}{N} \\
& \text { with: } \\
& X \quad=\text { core of each aspect } \\
& \Sigma X=\text { number score of each aspect } \\
& n \quad=\text { number of appraisers }
\end{aligned}
$$

5. Change the average score of each aspect of assessment of learning media in the form of quantitative data into qualitative criteria by the provisions in Table 2. Based on these provisions, it can be seen that the quality of learning media has been developed. 
TABLE 2. The criteria of Ideal assessment categories

\begin{tabular}{ccc}
\hline No & Score Range (i) & Category \\
\hline 1. & $\overline{\mathrm{Y}}>91,95$ & Very Good \\
2. & $76,65<\overline{\mathrm{Y}} \leq 91,95$ & Good \\
3. & $61,35<\overline{\mathrm{Y}} \leq 76,65$ & Enough \\
4. & $46,05<\overline{\mathrm{Y}} \leq 61,35$ & Less \\
5. & $\overline{\mathrm{Y}} \leq 46,05$ & Very Less \\
\hline
\end{tabular}

6. Determine the overall value of learning media by calculating the average score of all aspects of the assessment, then converted into qualitative values in accordance with the criteria of the ideal assessment category.

The data of students' response questionnaire against learning media is analyzed with the following steps:

1) Change the response of learners into an answer score by using Likert scale. For statements / questions that are positive, the answer score is strongly agree $(S A)=5$; agree $(A)=4$; doubtful $(D)=$ 3 ; disagree $(\mathrm{Da})=2$; strongly disagree $(S D a)=1$. For negative questions or statements i.e., $S A=1$; $\mathrm{A}=2 ; \mathrm{D}=3 ; \mathrm{Da}=4 ; \mathrm{SDa}=5[10]$.

2) Calculate the number of scores of each statement item according to the formula as follows:

The percentage of the result of students' response toward questionnaires

$=\frac{\text { total score }}{\text { Thenumber of student } \times \text { mark score }} \times 100 \%$

3) The data of calculative results above are then classified under the following conditions in Table 3.:

TABLE 3. Qualification percentage of student's responses

\begin{tabular}{ccc}
\hline No & $\begin{array}{c}\text { Percentage of Student's } \\
\text { Responses }\end{array}$ & Qualification \\
\hline 1. & $80,00 \leq$ percentage $\leq 100,00$ & Very Good \\
2. & $60,00 \leq$ percentage $\leq 80,00$ & Good \\
3. & $40,00 \leq$ percentage $\leq 60,00$ & Good Enough \\
4. & $20,00 \leq$ percentage $\leq 40,00$ & Enough \\
5. & $0,00 \leq$ percentage $\leq 20,00$ & Low \\
\hline
\end{tabular}

\section{RESULT AND DISCUSSION}

\section{Data of Development Process}

Chemo-entrepreneurship modeling on chemical bonding materials as an effort to cultivate the entrepreneurial spirit of students with disabilities in (Islamic) senior high school has been developed by using Borg and Gall's development model. Chemo-entrepreneurship modeling, hereinafter referred to as MEc Bond (Magnetic Educhem Bonding), is one type of learning media consisting of magnet board, atom and valence electrons equipped with magnets, manual usage, SPU table, and practice questions. The development of the MEc Bond is conducted through the review of two material experts, two learning media experts, two disability experts, and is given input by five (Islamic) senior high school teachers and two students with disabilities.

The process of arranging and developing the MEc Bond is carried out through several stages of development procedure:

1. The identification of potentials and problems, i.e., conducting preliminary research on chemistry learning in (Islamic) senior high school and its influencing factors, including curriculum, teachers, teaching materials, and student characteristics. Identification of potentials and problems is also focused on the selection of materials that conform to the concept of chemo-entrepreneurship in chemical bonding materials. 
This preliminary research is conducted through interviews and observations to chemistry teachers and students. The interview result shows that the chemical curriculum which is applied in (Islamic) senior high school refers to the 2013 curriculum. Chemistry learning for students with disabilities in (Islamic) senior high school is mixed with regular students. Teaching materials being used are textbooks from schools and dictations made by teachers. Teachers do not use special learning media for students with hearing impairment in chemical bonding material. Students with hearing impairment have difficulties in chemical bonding material especially in the sub-chapter of the Lewis structure because of its abstract materials. Therefore, when the development of this Bond MEc is proposed, the teachers feel happy and hope the learning media can be realized to help teachers in conveying the material of Lewis structure more concretely. Moreover, if the media is made with the concept of entrepreneurship, it can foster entrepreneurial spirit for students with hearing impairment.

Similarly, interviews which are conducted to students in grade XI of Sewon senior high school 1 and Islamic state high school 2 in Sleman, Teachers have not used learning media to teach chemical bond especially the chapter of Lewis structure. The teachers only use whiteboards, package books, and dictates in their lessons.

2. Select the product, i.e., selecting the product to be made tentative outline of what will be included on the product and how the product will be used, specific statement about the purpose of the product is made. The product will be developed to improve the understanding of chemical bond concept and entrepreneurial spirit of the students with disability by making the learning media of chemical bond in the form of three dimensional media using magnet (Magnetic Educhem Bonding (MEc Bond)). In this step, determine the design or parts of the MEc Bond. The parts include:

a. Magnetic board.

b. Atoms and electrons with magnets

3. Literature review, i.e., determining and taking into account the basic knowledge in the field which becomes the focus of research, in this case, research / review is focused on the literature which is related to the problem of student competence, chemo-entrepreneurship, and research development through journals and other supporting references.

At this stage, the type of magnet board is determined; the number of atoms and electrons will be made in accordance with the competencies that have to be achieved by the students based on the chemistry syllabus of tenth grade. The media are then made in order to have a good appearance, so it has a sale value. Based on the analysis to achieve student competence, atoms and electrons are made with the amount as follows:

TABLE 4. The data of atom and its number

\begin{tabular}{clcc}
\hline No & \multicolumn{1}{c}{ Name of Atom } & Symbol & Amount \\
\hline 1. & Hydrogen & $\mathrm{H}$ & 6 \\
2. & Boron & $\mathrm{B}$ & 1 \\
3. & Carbon & $\mathrm{C}$ & 2 \\
5. & Nitrogen & $\mathrm{N}$ & 2 \\
6. & Phosphorus & $\mathrm{P}$ & 2 \\
7. & Oxygen & $\mathrm{O}$ & 5 \\
8. & Sulfur & $\mathrm{S}$ & 1 \\
9. & Fluorine & $\mathrm{F}$ & 6 \\
10. & Chlorine & $\mathrm{Cl}$ & 6 \\
11. & Sodium & $\mathrm{Na}$ & 3 \\
12. & Magnesium & $\mathrm{Mg}$ & 3 \\
13. & Aluminum & $\mathrm{Al}$ & 2 \\
14. & Electron & $\mathrm{Oand} \mathrm{x}$ & 50 \\
\hline
\end{tabular}

4. Planning, i.e., determining the specific goals to be achieved by the product which will be made, the purpose of using the product, who the user of the product, the description of the components of the product and its use

In this step, certain goals can be determined by the presence of MEc Bond products, namely:

a. The purpose of product use

MEc Bond product is developed to facilitate students in studying chemical bonding materials, especially the sub- chapter of Lewis structure. This media can also be used by teachers as a 
model how to integrate chemical materials with entrepreneurial spirit. The concept of entrepreneurship, i.e., students can create a MEc Bond media with an attractive design, so that it can be sold. So, in addition to studying chemical bonding materials, students also learn to make the products of chemical bonding of learning media that has sale value.

b. Product users

Target use of this product includes: lecturers, students of chemical education, chemistry teachers or senior high school students.

c. Description of product components and its use

In general, this media consists of magnets, atoms and electrons with magnets.

5. The developing of the initial product draft is developed through cooperation with professionals or people who have the necessary skills for its developing. The experts who will be involved in this research are the material experts (especially the material of Chemical bound), the media experts (expertise who works in the field of making learning media which has the sale value leconomy), disability experts at this point, after designing media, it will be conducted FGD with material experts, media experts, and disability experts. Furthermore, after being discussed, the media which has been planned is printed in the early stage.

6. Initial field trials and product revisions, in this case, a preliminary test is conducted through an initial product assessment by two material experts, two media experts, and two disability experts.

After the initial draft and refinement through FGD activities, the next step is that initial trial is conducted. This stage involves several experts, i.e., material experts, learning media experts, and disability experts.

a. Review by material experts

1) Overall, valence electrons use dot (.) and are distinguished into red and yellow. There are an additional 10 valence green electrons to signify coordination covalent bonds

2) The atomic color is adjusted with the elements in molymod, such as carbon (black), hydrogen (blue), oxygen (red), nitrogen (dark blue), and others.

3) Use a permanent magnet in order to be able to be durable because the magnetism of iron can disappear faster.

b. Review by media experts

4) The product name is attached.

5) The color of the atom is made differently so it is easy to look for.

6) The board is packed again in order to be more flexible in carrying it.

c. Review by disability experts

1) Instructions on how to use for students with hearing impairment.

2) The language which is used in the instruction manual should be simple or using basic words.

3) Atom which is made is only atom that is important so it is not too much.

4) Media should be made simply to be easily remembered by students with disabilities.

The suggestions from material experts, learning media specialists, and disability experts are used to improve the initial draft of the product. Furthermore, the product of media will be tested.

7. Field trials of the main stage (small scale) and product revision are small-scale experiments, i.e., five chemistry teachers and two students with hearing impairment. The initial product which has been revised based on input from experts is tested in a limited way toward five chemistry teachers from Sewon senior high school 1; Islamic senior high school 2 in Sleman; and Muhammadiyah 4 Senior high school Yogyakarta; and two students with hearing impairment in Sewon senior high school 1. The inputs from chemistry teacher to learning media of MEc Bond are as follows:

a) MEc Bond Media is very creative and helps teachers to explain the sub-section of the Lewis structure.

b) Except for students with disability, media is also useful for regular students.

c) Elements are made for more so that the formula resulted is a lot more.

d) There are some magnets rejecting each other, so that it makes difficult to storage.

e) There is packing of magnet board and media for easy carrying and storage.

f) If it is sold, the price should not be too expensive for schools to have this learning medium.

g) Create media for classical learning and group work. The size of the classical media is made larger than the size for group work.

Input from students with disabilities is that the media is very interesting and necessary for learning in the classroom. 


\section{The Product of Development Results}

The product of the development results is learning media of MEc Bond (Magnetic Educhem Bonding) for students with hearing impairment in (Islamic) senior high school based on chemo-entrepreneurship Modeling. Mostly, the learning media consists of:

1. Magnetic Board

The magnetic board used consists of two sizes: a magnetic board for classical and group work. The magnetic board for classical learning has a size $(53 \times 42)$ and the magnet board for group work has a size $(40 \times 30)$.

2. Atoms and electrons

Atoms and electrons are made of acrylic with the back of a magnet. The number of atoms and electrons which are used consist of:

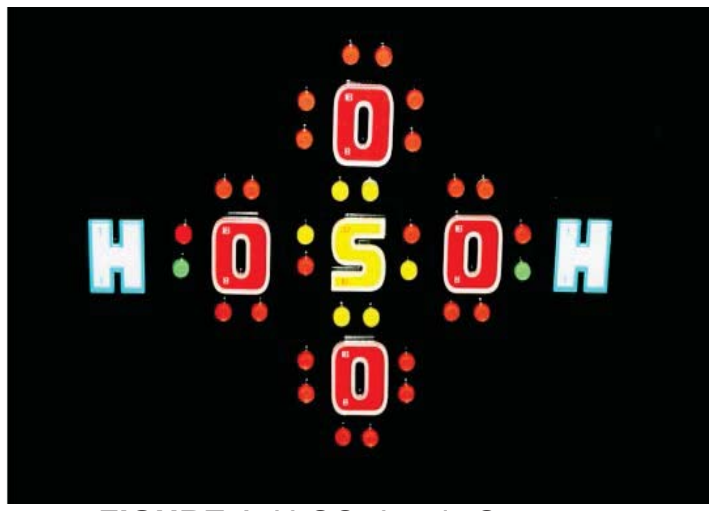

FIGURE 1. $\mathrm{H}_{2} \mathrm{SO}_{4}$ Lewis Structure

TABLE 5. The data of atom and its number after revision

\begin{tabular}{llcc}
\hline No & Name of Atom & Symbol & Amount \\
\hline 1. & Hydrogen & $\mathrm{H}$ & 6 \\
2. & Boron & $\mathrm{B}$ & 1 \\
3. & Carbon & $\mathrm{C}$ & 2 \\
4. & Nitrogen & $\mathrm{N}$ & 2 \\
5. & Phosphorus & $\mathrm{P}$ & 2 \\
6. & Oxygen & $\mathrm{O}$ & 5 \\
7. & Sulfur & $\mathrm{S}$ & 1 \\
8. & Fluorine & $\mathrm{F}$ & 6 \\
9. & Magnesium & $\mathrm{Mg}$ & 1 \\
10. & Electron & $\mathrm{O}$ & 10 \\
11. & Electron & & \\
& & $\mathrm{O}$ & 50 \\
12. & Electron & & 10 \\
\end{tabular}

3. Plastic box

plastic box is functioned as atom container, and instructions for use.

4. Instructions for Use

Usage instruction is packaged in order to fit in a plastic box. 


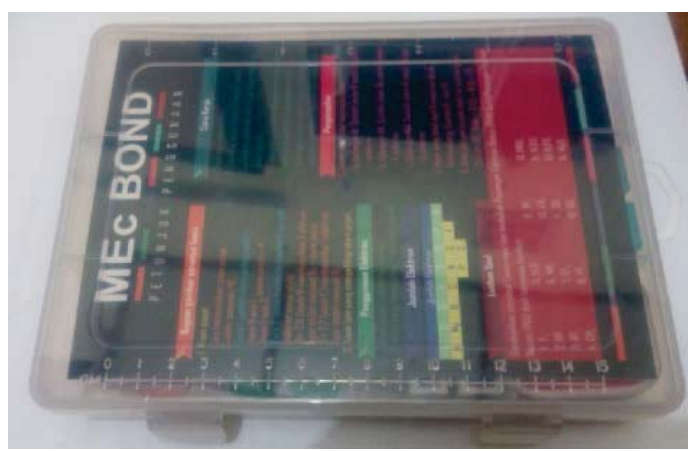

FIGURE 2. Plastic box for storage of atoms, electrons, and instructions for use

\section{MEc Bond Product Quality Data and Its Analisys}

The quality of MEc Bond products is revealed through a major stage field trial. A total of five chemistry teachers from Sewon senior high school 1 and Islamic state high school 2 in Sleman and Muhammadiyah 4 Senior high school Yogyakarta are involved to assess the Bonding MEc product. Table 4 below is a recapitulation of the assessment results of the five teachers in each aspect of the assessment.

TABLE 6. Recapitulation of the assessment results of the teachers toward MEc Bonding

\begin{tabular}{llccc}
\hline No & Assessment Aspect & Total score & $\begin{array}{c}\text { Average } \\
\text { score }\end{array}$ & Percentage (\%) \\
\hline A. & Relating to teaching materials & 69 & 138 & 92 \\
B. & The value of education & 66 & 132 & 88 \\
C. & Equipment resistance & 68 & 13.6 & 90.6 \\
D. & The accuracy of the tool & 45 & 9 & 90 \\
E. & Efficiency & 50 & 10 & 100 \\
F. & Disability & 67 & 13.4 & 89.3 \\
G. & Esthetics & 67 & 13.4 & 89.3 \\
H. & Entrepreneurship & 89 & 17.8 & 89 \\
\hline
\end{tabular}

Generally, based on eight aspects of the assessment, the results of teacher assessments of MEc Bond products can be summarized as follows.

Ideality Percentage of each MEc Bond assessment

aspect

100
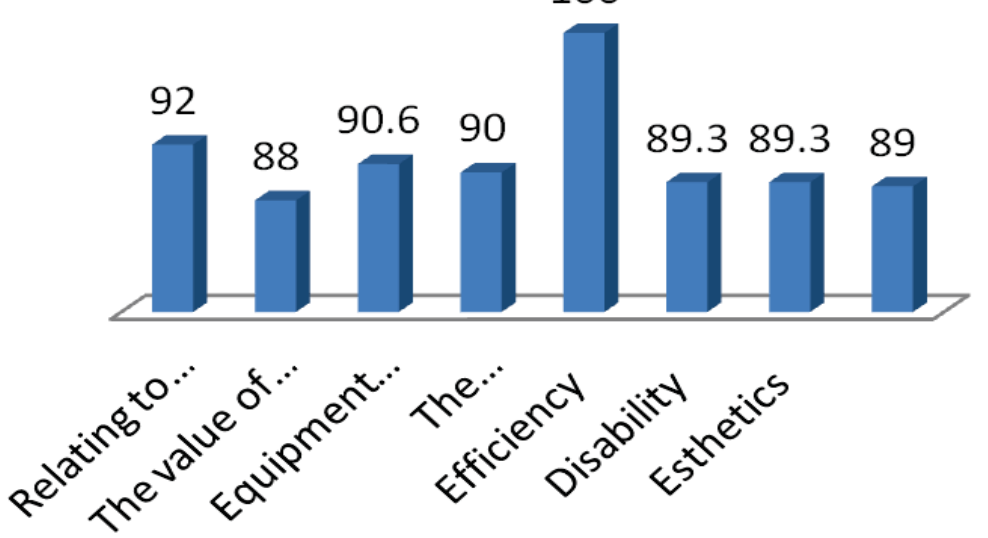

FIGURE 3. Ideality percentage of each MEc Bond assessment aspect 
Based on Figure 3., it can be seen that the efficiency aspect gets the highest score, that is 100. According to the teacher's description, MEc Bond media is something that is creative and very much required in the study of chemical bonding material. Through this media, students are expected to no longer delete in multiple times in making Lewis structures in notebooks. Students can create a Lewis structure simply by moving/shifting the atoms and its valence electrons on magnet board while playing. MEc Bond media is also easy to assemble, use, and can make abstract material more concrete. In addition, the teacher is happy, because with the MEc Bond media teachers do not experience any more trouble to explain the material of Lewis structure that is abstract. Even through this media, teachers are inspired to further develop other teaching materials that can make it easier for students to understand the subject matter of chemistry. Teachers also state that MEc Bond media is indispensable in schools to make it easier to study chemical bonding material. Nevertheless, teachers suggest that the media is packaged for classical learning and group work and the selling price of MEc Bond media is not too expensive so schools can afford it.

The lowest score was obtained on the educational value aspect, which was 88. According to the teacher, the indicator of conformity with students' intellectual development and enhanced competence on students for MEc Bond media does not influence significantly. While making the abstract material into concrete can get the maximum value.

The average score of MEc Bond learning media quality is 104.2. Based on the ideal category assessment, the result obtained is greater than 91.95 so it can be concluded that the media which is resulted is categorized as very good (VG).

Besides teachers, as many as two students with hearing impairment from Sewon senior high school 1 are also involved to provide responses related to MEc Bond learning media. Here are the results of deaf students' responses to MEc Bond learning media that can be seen in Table 5.

TABLE 7. Recapitulation of result of deaf students' response to MEc Bond learning media

\begin{tabular}{clcc}
\hline No & \multicolumn{1}{c}{ Statement } & Total score & Percentage (\%) \\
\hline A. & MEc Bond learning media is easy to use & 10 & 100 \\
B. & $\begin{array}{l}\text { MEc Bond learning media can encourage me to } \\
\text { study cemistry }\end{array}$ & 7 & 70 \\
C. $\quad \begin{array}{l}\text { MEc Bond learning media can facilitate me to } \\
\text { understand the concept of Lewis structure }\end{array}$ & 9 & 90 \\
D. $\quad \begin{array}{l}\text { The appearance of MEc Bond learning media is } \\
\text { interesting }\end{array}$ & 8 & 90 \\
E. $\quad \begin{array}{c}\text { MEc Bond learning media needs to be used to } \\
\text { learn in class. }\end{array}$ & 90 \\
\hline
\end{tabular}

Based on Table 5., it can be concluded that MEc Bond learning media is easy to use (statement number 1 in questionnaire). MEc Bond learning media is easy to use because in creating Lewis structure, students simply shift / move the atom and its valence electrons on the magnet board. The lowest response which is given by students with hearing impairment is in statement number 2: "Learning media of MEc Bond can motivate me to study chemistry". Students whit hearing impairment do not experience the MEc Bond learning media can motivate them to learn chemistry. The percentage of learners' responses to MEc Bond learning media is $86 \%$ so that it can be concluded that learners' response to the media learning MEc Bond is very good (VG).

\section{CONCLUSION}

Based on the results of data analysis and discussion, it can be drawn conclusion below:

1. The results show that the learning media of MEc Bond (Magnetic Educhem Bonding) for students with hearing impairment in (islamic) senior high school based on chemo-entrepreneurship modeling has been developed with input from validators and chemistry teachers.

2. The learning media developed has excellent quality according to the assessment of chemistry teachers of (islamic) senior high school with the percentage of ideality of $91.02 \%$.

3. In general, students with hearing impairment respond positively (questionnaire results indicate $86 \%$ percentage of ideality) in the presence of MEc Bond (Magnetic Educhem Bonding) learning media 
which makes chemical bonding material more easily to be understood and fun. In addition, the media is required for the study of chemical bonds in the classroom and can foster the entrepreneurial spirit of students in the form of making learning media of chemical bonds that has value of sale/economic power.

\section{REFERENCES}

1. S. Winarsih, H. Jamal, A. Asiah, F. H. Idris, E. Adnan, B. Prasojo, I. Tan, A. A. Masyhuri, Syafrizal, S. Majid, N. Hasnul, A. Riyanto, L. Bunawan, C. Rukiyah and I. K. Sembada, Panduan Penanganan Anak Berkebutuhan Khusus bagi Pendamping (Orang Tua, Keluarga, dan Masyarakat (Kementerian Pemberdayaan dan Perlindungan Anak, Jakarta, 2013).

2. D. F. Kuratko, Entrepreneurship Theory and Practice, 29, 5, 577-598 (2005).

3. A. T. Hananta, Jurnal Pendidikan Guru Sekolah Dasar,16, 4, 3-11 (2015).

4. L. Dewi, A. Yani and A. D. Suhardini, Mimbar, 31, 2, 399-408 (2015).

5. H. K. Wu, J.S. Krajcik and E. Soloway, J. Res. Sci. Teach, 38, 7, 821-842 (2001).

6. Sudijono, Pengantar Statistika Pendidikan (CV Rajawali, Jakarta, 2009).

7. Muzaphire and I. Ramadhani, Jurnal Inklusi, 2, 2, 243-258 (2015).

8. R. W. Borg and M.D. Gall, Educational Research; An Introduction, Fifth Edition (Longman, New York: 1989).

9. Z. Arifin, Penelitian Pendidikan: Metode dan Paradigma Baru (PT. Remaja Rosdakarya, Bandung, 2012).

10. S. E. P. Widoyoko, Evaluasi Program Pembelajaran (Pustaka Pelajar, Yogyakarta, 2012). 